\title{
Essential but Excluded: Using Critical Race Theory to Examine COVID-19 Economic Relief Policies for Undocumented US Workers
}

\author{
Lindsey Disney ${ }^{1}\left[\right.$ Jinhee Koo ${ }^{1} \cdot$ Stephanie Carnes ${ }^{1} \cdot$ Lynn Warner $^{1}$
}

Accepted: 19 October 2021 / Published online: 13 January 2022

(C) The Author(s), under exclusive licence to Springer Nature Switzerland AG 2021

\begin{abstract}
Following the onset of the COVID-19 pandemic, undocumented immigrants in the United States were vulnerable both to unemployment and to COVID-19 infection if they did remain employed, because of the sectors that employ them. Despite these heightened economic vulnerabilities, 7.8 million undocumented workers were excluded from federal economic relief policies. This article uses critical race theory (CRT) to examine the intentional and unjust exclusion of undocumented U.S. workers from COVID-19 economic relief aid within the larger context of economic marginalization and injustice. It also provides an overview of the major federal economic relief legislation and policy developments during the first year of the COVID-19 pandemic in the United States, between March 2020 and July 2021. While some states have enacted creative programs and policies related to COVID-19 economic relief, effective and comprehensive federal-level policies must be implemented to address the growing chasm of inequity in American society, particularly as experienced by often-essential undocumented immigrant workers. Specific standards related to work and quality of live are protected by the United Nations Universal Declaration of Human Rights (1948), but exclusionary federal policies render these minimum standards inaccessible for undocumented workers and deepen existing economic and social disparities. Social work aspires to provide a uniquely critical and social justice-minded perspective that considers systems of oppression, power dynamics, and human rights, and this perspective can contribute to socially just economic policy development.
\end{abstract}

Keywords COVID-19 $\cdot$ Critical race theory $\cdot$ LatCrit $\cdot$ Economic relief policies $\cdot$ Undocumented $\cdot$ US immigrants $\cdot$ Human rights $\cdot$ Worker rights

\section{The Economic Vulnerability of Undocumented US Workers}

The COVID-19 pandemic has generated dire economic consequences for the approximately 11 million undocumented immigrants in the USA (Clark et al., 2020). In the USA, undocumented immigrants are considered to be foreign nationals who are in the USA without immigration documentation, such as a visa, and do not have permission to work (Reed, 2018). Of this population, the majority is Spanish-speaking, with 68\% from Central America and Mexico and $14 \%$ from Asia. Seventy nine percent of the undocumented US population is aged 25 and older, and 54\% are male (Migration Policy Institute [MPI], 2018).

Lindsey Disney

ldisney@albany.edu

1 School of Social Welfare, University at Albany, Albany, NY, USA
Approximately 7.8 million undocumented immigrants are estimated to participate in the workforce, and undocumented workers tend to be employed in low-paying jobs, earning wages well below established federal poverty levels (Passel \& Cohn, 2018).

Despite a $72.8 \%$ rate of employment among undocumented immigrants (Passel \& Cohn, 2018), 68\% of undocumented adults report lacking health insurance (Goldman et al., 2005). As a result, undocumented workers are far less likely to have necessary healthcare benefits to secure COVID-19 testing and treatment (Gomez \& Meraz, 2021; Kerwin \& Warren, 2020), and may be unwilling due to fears of public charge repercussions (Gomez \& Meraz, 2021). The "public charge" rule was a policy under the Trump administration which counted public benefit usage as a strike against eligibility for a green card or other visas (Capps et al., 2020b). Undocumented immigrants are similarly unable to access COVID-related financial safety nets, such as paid sick leave, childcare supports, and family sick 
leave; if they do contract COVID-19, they simultaneously confront devastating health and financial outcomes.

Additionally, undocumented immigrant workers are heavily represented in the employment sectors most impacted by the pandemic, such as building services, food production services, healthcare, hospitality industry, and retail (Zamarripa \& Roque, 2021). Nearly one-third of essential workers in the United States are immigrants, and $74 \%$ of undocumented workers are essential workers (Kerwin \& Warren, 2020; Zamarripa \& Roque, 2021). Following COVID-19 pandemic shut down policies implemented between February and April 2020, the unemployment rate of Latinx immigrant workers in the USA spiked higher and faster than that of White workers (Gould et al., 2020). Additionally, while unemployment increased across all demographic groups during the first months of the pandemic, Latinx female immigrants had the highest jobless rate of 22\% (Capps et al., 2020a, b). Similarly, Latinx Americans represented significantly higher job losses in 2020, with a reported unemployment rate in January 2021 of $8.6 \%$ compared to 5.7\% among White Americans (Zamarripa \& Roque, 2021). During the early months of the pandemic, the number of employed immigrants declined from 27.6 million to 21.9 million (US Congress Joint Economic Committee, 2020). These figures highlight the enduring economic vulnerability of immigrant workers, which was magnified during the COVID-19 pandemic.

Finally, while the disproportionate risk of exposure to COVID-19 faced by essential workers could be significantly mitigated by vaccination, vaccine disparities persist in undocumented populations even though essential workers are included in priority groups for vaccination (Artiga et al., 2021). Without vaccination, workers are at risk for both wage loss and health costs if they do contract COVID-19. Such disparities may be due to fear of personal data collection related to legal status and lack of sick time from employment to manage vaccine side effects (Artiga et al., 2021).

Pre-pandemic, undocumented workers were financially vulnerable because of the absence of health insurance, low-paying jobs, public charge rules, and exclusion from financial safety nets. Since the pandemic, undocumented workers are even more financially vulnerable. Many are essential workers, employed in sectors such as healthcare, food services, and public transportation, with disproportionate risk of exposure to COVID-19 (Zamarripa $\&$ Roque, 2021). Vaccine disparities further contribute to the economic vulnerability of the undocumented worker. Yet, these US workers do not have the same employmentrelated protections as other workers who are documented, contributing to the broader social exclusion of undocumented immigrants (Luyten \& Beutels, 2016).

\section{A Critical Race Theory Lens and US COVID-19 Economic Relief Policies}

Critical race theory (CRT) provides a lens for critiquing the exclusion of undocumented workers from US federal economic relief policies within the larger context of economic injustice and social exclusion (Delgado \& Stefancic, 2017). CRT was developed in the 1970s to conceptualize and critique power imbalances and structural inequities as they relate to race and the law; however, the tenets of CRT allow for critique of other systems of oppression, and scholars have applied CRT to examine the policies and practices of other fields including education, public health, and social work (Delgado \& Stefancic, 2017; Maldonado, 2021). Latinx critical theory, or LatCrit, is a complementary framework to CRT that considers how Latinx identity interacts with societal dynamics, including racism, nativism, and xenophobia (Delgado Bernal, 2002; Pérez Huber, 2010). LatCrit adds an additional layer of understanding the nuances of marginalization and oppression experienced by the $68 \%$ of undocumented immigrant workers whom identify as Latinx.

CRT and LatCrit emphasize the importance of critiquing policies and policy making within the historical and societal context. Thus, the lack of responsive economic policies for the essential but excluded undocumented population must be contextualized, as the USA has historically adopted short-sighted and dehumanizing policies vis a vis undocumented immigrants, such as parent-child separation and child detention (Wood, 2018). Such policies are also implemented against the backdrop of the national racism pandemic, a pandemic characterized by the physical and mental health consequences of structural violence and discrimination experienced by Black people in the USA (Bright, 2020). In short, US federal relief policies have displayed a lack of care for the lives of undocumented workers in particular and, more broadly, people of color, and current COVID-19 economic relief policy development is merely a continuation of a long-standing pattern (Cross \& Gonzalez Benson, 2021; Solomon et al., 2019).

Through the lens of CRT, economic policies are understood to be explicitly developed to maintain social and economic inequality, so that people in power remain in power and that the White, neoliberal-dominant status quo endures (Constance-Huggins, 2012; Delgado \& Stefancic, 2017; Romich \& Rodriguez, 2021). Indeed, the whole US economic system is grounded in exploiting and subjugating people of color, and the current policies contributing to economic marginalization and injustice have been the experience of undocumented immigrant workers long before the pandemic's emergence in the United States in 2020 (Solomon et al., 2019). For example, even though undocumented workers 
pay into employment-related benefits, including unemployment insurance, social security, and Medicaid, through the individual taxpayer identification number (ITIN) system, they are unable to access those compensation benefits (NILC, 2012). The ITIN system was instituted by the U.S. Internal Revenue System (IRS) to provide a mechanism for US workers who do not have, and are not eligible to obtain, social security numbers to pay taxes (American Immigration Council, 2020). In 2014, \$23.6 billion of tax money was paid through the ITIN system (American Immigration Council, 2020). Expecting 7.8 million U.S. workers to pay into a tax system from which they have no right to access is a denial of work-related rights (United Nations [UN], 1948). According to the United Nations Universal Declaration of Human Rights (UDHR), Article 23, (1948), all workers have the following human rights:

Everyone has the right to work, to free choice of employment, to just and favorable conditions of work and to protection against unemployment. Everyone, without any discrimination, has the right to equal pay for equal work. Everyone who works has the right to just and favorable remuneration ensuring for himself and his family an existence worthy of human dignity, and supplemented, if necessary, by other means of social protection.

Additionally, as protected by Article 25 of the International Convention on the Protection of the Rights of All Migrant Workers and Members of Their Families (1990), the health and safety of migrant workers are specifically safeguarded:

Migrant workers shall enjoy treatment not less favourable than that which applies to nationals of the State of employment in respect of remuneration and: (a) Other conditions of work, that is to say, overtime, hours of work, weekly rest, holidays with pay, safety, health, termination of the employment relationship and any other conditions of work which, according to national law and practice, are covered by these terms.

From a CRT lens, the ITIN system intentionally perpetuates economic disparity that benefits White Americans (Lipman, 2006). In fact, contributions from ITIN filers have contributed up to $10.7 \%$ of the Social Security Trust Fund ( $\$ 240$ billion as of 2007) and helped to forestall the Trust Fund's solvency crisis - ultimately benefiting the long-term financial security of the White native-born worker at the expense of the undocumented US worker, who is very likely a person of color (National Immigration Law Center [NILC], 2012). And, according to the CRT tenet of interest convergence, those in power will not support fair economic policies - such as allowing those with an ITIN to access employment-related benefits - because such change would reduce their privileges (Delgado \& Stefancic, 2017). Thus, the US government legally mandates undocumented workers to pay taxes through the ITIN system, while simultaneously maintaining an immigration policy that undocumented workers are not authorized to work in the USA (Frost, 2016; Lipman, 2006). If the US government wanted to enforce immigration policy and deport undocumented workers, this could easily be done through the personal information provided via the ITIN database (Frost, 2016). Or, if the US government wanted to include undocumented workers as recipients of economic relief policies during a time of national economic crisis, this could also easily be done through the existing ITIN system. The message sent is clear-you are welcome to work here and pay taxes here, but do not expect to be treated with the same human rights as everyone else.

Similarly, undocumented workers are ineligible for most federal social protection initiatives, particularly incomebased benefits such as Supplemental Nutrition Assistance Program (SNAP), non-emergency Medicaid, Temporary Assistance for Needy Families (TANF), and Supplemental Security Income (SSI) (National Migration Forum, 2018). Several states, including California, Illinois, Massachusetts, New York, Oregon, and Washington, as well as Washington, D.C., offer ad-hoc state-funded benefits to counter this structural injustice, such as free or low-cost health insurance programs for undocumented children (Artiga \& Diaz, 2019). However, the public charge rule, implemented by the Trump administration in 2019, has acted as a deterrent for many undocumented immigrants who would have otherwise benefitted from such initiatives, including recent COVID19-related initiatives such as free COVID-19 testing and treatment (Capps et al., 2020b). The rule, which counted public benefit usage as a strike against eligibility for legal relief, had particularly devastating implications for undocumented immigrants seeking to obtain legal status in the USA (Capps et al., 2020b). Undocumented immigrants were thus confronted with the choice of facing immediate economic hardship without the mitigating effect of limited public benefits or risking long-term ineligibility for legal status. Although the Biden administration ceased enforcement of the public charge rule in March 2021, the administrative rule continues to intimidate and discourage many undocumented immigrants from accessing public services for fear of future immigration consequences (Gomez \& Meraz, 2021). These fears also impact the benefits that undocumented parents are willing to access for their children, who are primarily US citizens (Artiga \& Diaz, 2019).

Lastly, CRT also explains how widespread narratives of undocumented workers as taking more from the US government than they contribute, or stealing American jobs, persist despite being historically and presently untrue (Frazee, 2018; Flores Morales \& Farago, 2021). CRT argues that these false narratives provide justification (storytelling) for inequitable 
economic policies that continue to advance the privileges of those who are white and those with power (Hartlep, 2009; Maldonado, 2021). CRT also highlights how storytelling is an intentional deception by the politically powerful and is in part effective because the majority of white benefactors have no economic reason to challenge the narrative (Bernal, 2002).

\section{Undocumented US workers excluded from federal COVID-19 economic relief policies}

The following is an overview of the major federal economic relief legislation during the first year of the COVID-19 pandemic, from March 2020 to July 2021, and assessment of the extent to which eligibility requirements include or exclude undocumented immigrants. The analysis considers undocumented immigrant individuals as well as mixed-status families who were also ineligible from many economic relief policies, despite having documented or US citizen family members (Lahoud, 2021). Mixed-status families are households who have at least one undocumented family member living with them. There are approximately 16.7 million people in the USA who live in a mixed-status household (Lahoud, 2021). Scholars of CRT and LatCrit might suggest that exclusion from a social safety net because of a family member's legal status is an example of how economic policies are created to disadvantage both immigrants and citizens of color (Romero, 2008).

Enacted federal legislation is presented first, followed by federal policy initiatives that included undocumented workers as eligible, but did not pass. The two federal policy initiatives failed to become enacted because of their attempts to extend eligibility to undocumented workers and families, either centrally (Coronavirus Immigrant Families Protection Act) or in part (Health and Economic Recovery Omnibus Emergency Solutions). From the lens of CRT, these policy initiatives did not pass because they would have increased the financial security of the undocumented immigrant worker while reducing the economic privilege of the white, native-born worker. State economic relief policies to support undocumented workers and families are also included as exemplars for their potential to remedy disparities in other states or nationally.

\section{Legal Status Eligibility Requirements for US Federal COVID-19 Economic Relief Policies}

Please also see Table 1 legal status eligibility requirements for U.S. federal COVID-19 economic relief policies and policy initiatives.

\section{Coronavirus Aid, Relief, and Economic Security (CARES) Act (H.R. 748): March 2020}

The Coronavirus Aid, Relief, and Economic Security Act, or CARES Act, a $\$ 2.2$ trillion stimulus bill, was signed into law on March 27, 2020. The CARES Act included direct stimulus payments to households and new unemployment insurance benefits (Bhutta et al., 2020). Although the CARES Act constitutes the largest economic relief bill in US history, its beneficiaries are largely USborn workers. The legislation does not alter eligibility criteria for Medicaid, leaving many immigrants - particularly those without legal status in the USA and those within mixed-status families - with few options for affordable, accessible COVID testing and care. While the CARES Act did broaden the scope of unemployment insurance programs through the Pandemic Unemployment Assistance (PUA) initiative, which extends economic relief to self-employed, part-time, and contract workers, such programs remained outside the reach of the undocumented immigrant population (NILC, May 2020b). Additionally, the CARES Act issued advanced rebates of up to $\$ 1200$ for individual taxpayers and $\$ 2400$ taxpayers who filed jointly; however, undocumented workers are denied the formal work authorization and related identification required to obtain the financial assistance contained in the CARES legislation, despite contributing $\$ 11.74$ billion to state and local taxes annually (Fiscal Policy Institute [FPI], 2021); mixed-status households were also ineligible. Finally, the CARES Act allotted $\$ 14$ billion to the Office of Postsecondary Education through the Higher Education Emergency Relief Fund (HEERF) for student emergency relief aid; however, undocumented, deferred action for childhood arrivals (DACA) and temporary protected status (TPS) students are not eligible (Gomez \& Meraz, 2021). DACA and TPS recipients are protected from deportation and permitted to work. Undocumented immigrants are eligible to apply for the DACA program if they entered the USA before the age of 16 years old, are between the ages of 15 years old and were under the age of 31 years old in 2012, and have been in the USA for at least 4 years (Singer \& Svajlenka, 2013). Since the program's inception in 2012, there have been 825,000 DACA recipients (Svajlenka \& Wolgin, 2020). Undocumented immigrants are eligible to apply for the TPS program if they are a national of a country that is designated a TPS country by the USA. Current TPS-designated countries include Burma (Myanmar), El Salvador, Haiti, Honduras, Nepal, Nicaragua, Somlia, South Sudan, Sudan, Syria, Venezuela, and Yemen (Congressional Research Service [CRS], 2021). As of 2021, there were approximately 320,000 immigrants protected with TPS. 


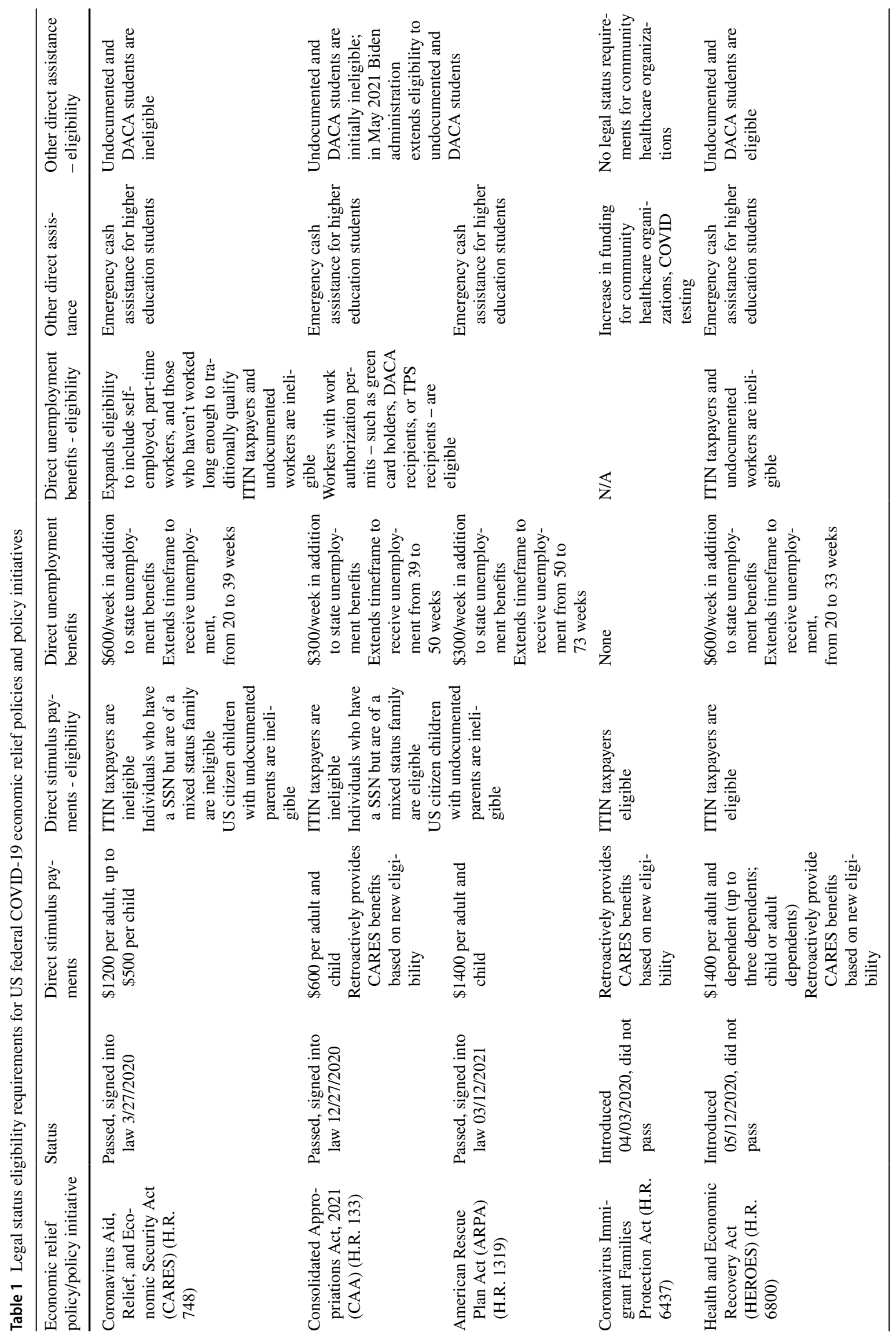




\section{Consolidated Appropriations Act, 2021 (CAA) (H.R. 133): December 2020}

The Consolidated Appropriations Act, 2021 (CAA) (H.R. 133 ), a $\$ 2.3$ trillion stimulus bill, was signed into law on December 27, 2020. The CCA also included direct cash assistance in the amounts of $\$ 600$ per adult and child. Unfortunately, ITIN taxpayers and US citizen children with undocumented parents remain ineligible. Positively, CCA does include individuals who have a social security number but are of a mixed-status family and retroactively allows for the CARES cash benefits based on this new eligibility. ITIN and other undocumented workers remain ineligible for unemployment benefits, and undocumented, DACA, and TPS students remain ineligible for emergency financial assistance.

\section{American Rescue Plan Act (ARPA) (H.R. 1319): March 2021}

The American Rescue Plan Act (ARPA), a \$1.9 trillion economic relief and social welfare initiative, was signed into law on March 11, 2021. Similar to the CARES Act, the ARPA stimulus package included state and local economic support, direct payments, housing assistance, funding for comprehensive COVID tracing, testing, and treatment, and additional streams of unemployment assistance. Specifically pertinent to the undocumented immigrant population, ARPA provides increased funding to community health centers, which undocumented immigrants often rely on for low-cost healthcare. Undocumented workers are once again ineligible to receive the $\$ 1400$ cash payment, which is arguably the most individually impactful provision of ARPA; however, American-born or naturalized children of undocumented immigrants and documented members of mixed-status families are eligible. Undocumented and DACA students are initially ineligible for emergency student financial assistance; however, on May 11, 2021, the Biden administration extended eligibility to undocumented and DACA students.

\section{Legal Status Eligibility Requirements for US Federal COVID-19 Economic Relief Policy Initiatives that Did Not Pass}

\section{Coronavirus Immigrant Families Protection Act (H.R. 6437): April 2020}

On April 3, 2020, the Coronavirus Immigrant Families Protection Act (H.R. 6437) was introduced specifically to fill the gaps in economic relief provided by the CARES Act. This proposed legislation addressed the structural barriers to COVID testing and care faced by immigrants as well as the economic consequences of the pandemic that have been experienced disproportionately by the immigrant community. A broad initiative, H.R. 6437, sought to postpone Immigration and Customs Enforcement (ICE) activities that would deter immigrants from accessing COVID testing or treatment, suspend the public charge rule during the pandemic, initiate a COVID19-related public information campaign targeting vulnerable and marginalized populations, and allow undocumented immigrant taxpayers to access economic relief opportunities via their individual tax identification number (as opposed to social security number holders only). H.R. 6437 would also have retroactively allowed for the CARES cash benefits based on this new eligibility. While such legislation could have mitigated the deleterious economic and public health consequences of the pandemic on the American immigrant population in particular, it failed to garner necessary support for enactment.

\section{Health and Economic Recovery Omnibus Emergency Solutions (HEROES) Act (H.R. 6800: May 2020}

In recognition of the inequity imbedded in the CARES Act, the Health and Economic Recovery Omnibus Emergency Solutions Act (hereafter the HEROES Act) was proposed by House Democrats on May 12, 2020, and passed on May 15, 2020, as a supplemental $\$ 3$ trillion relief package. An updated version of the bill was passed by the House on Oct. 1, 2020. Included in the HEROES Act were direct federal assistance to state and local governments, a federally funded pay increase for essential workers, an extension to the previously enacted federal supplement to unemployment benefits, recovery rebates for those with ITIN numbers, increased access to non-emergency Medicaid, direct and indirect housing assistance to consumers, and the extension of legal relief for those with expiring immigration status, including DACA and temporary protected status (TPS), during the national emergency. The HEROES Act also included provisions for free COVID testing and treatment for undocumented and mixed-status families and established basic standards for COVID-19 care in immigrant detention facilities. The HEROES Act was a critical piece of legislation to increase economic and health equity for immigrants during the pandemic, particularly those without legal status, and would have been a step toward acknowledging and honoring the sacrifices made by undocumented essential workers (Werner, 2020). However, the legislation faced significant opposition along partisan lines and was ultimately blocked by a Republican-controlled Senate.

\section{US State and Local COVID-19 Economic Relief Policies to Support Undocumented Workers}

In the absence of a responsive and comprehensive national policy to address the pressing economic needs of immigrants - particularly those without legal status -individual 
states and cities created a wide range of innovative stopgap economic measures during the pandemic (Suro \& Findling, 2020). Ultimately, however, the absence of a coherent federal response manifests in dramatic variations in policy responses at the state level. Some states and municipalities have enacted measures, often in collaboration with charitable organizations and community partners, that may be considered exemplars in the fight against economic and social marginalization (Suro \& Findling, 2020). State and local governments are either paying entirely with state taxpayer dollars or drawing on philanthropic dollars for some or all of the funding and for help in distributing funds (Suro \& Findling, 2020).

Speaking directly to the exclusion of undocumented workers from federal economic stimulus provisions and cash assistance programs, California's disaster relief fund distributed $\$ 75$ million of state funding and $\$ 50$ million of private funding to undocumented workers in the form of $\$ 500$ one-time cash payments (NILC, April 2020a). Supported by a statewide coalition of community organizations, the Oregon Worker Relief Coalition similarly provides temporary financial assistance to undocumented workers (Suro \& Findling, 2020). In New York City, a partnership between the city government and the Open Society Foundation allowed up to 20,000 undocumented workers and their families to access a one-time cash benefit of up to $\$ 1000$ per family (The Mayor's Office, City of New York, 2020). In April of 2021, the New York State passed the Excluded Worker Fund, a \$2.1 billion plan to provide lump-sum payments to undocumented workers (FPI, 2021). Under the plan, undocumented workers may apply for benefits as large as $\$ 15,600$ if they are able to show that they worked in-state and that they were economically impacted by the pandemic (FPI, 2021). In Boston, the Boston Resiliency Fund, supported by donations of private citizens and local groups, dispersed over $\$ 25$ million to local organizations serving the undocumented immigrant community, including community health organizations and food pantries. Los Angeles' Angeleno Card initiative offers $\$ 700-\$ 1500$ to low-income residents of Los Angeles who have experienced financial hardship, regardless of immigration status (NILC, 2020a, b).

In addition to extending cash assistance to those left out of federal level initiatives, many states and municipalities have implemented other economic relief programs that do not have legal status eligibility requirements, including housing assistance, funeral assistance, and permanent measures to help, such as through expanded tax credits or expanded Medicaid eligibility. For example, during the pandemic, Illinois expanded Medicaid coverage to all low-income children and seniors regardless of immigration status (Suro \& Findling, 2020). In Los Angeles,
California, the Emergency Rental Assistance Subsidy Program was created, and undocumented immigrants are eligible for assistance, with qualifications based primarily on income (Suro \& Findling, 2020). As of March 2021, California, Colorado, and Maryland have passed legislation allowing many low-income taxpayers, including those undocumented, to earn an earned income tax credit (EITC) (Lahoud, 2021). Thirty states have followed their lead with their own versions of the EITC that provide some support for undocumented workers (Suro \& Findling, 2020).

\section{Discussion and Recommendations}

U.S. policies meant to address public health and economic recovery during the COVID-19 pandemic have failed to protect the emotional, physical, and economic well-being of undocumented workers (Godlee, 2020). As a result, the economic distress faced by millions of undocumented US workers during the pandemic has been compounded by systematic exclusion from federal COVID-19 economic relief policies. While the nascent Biden administration has explicitly acknowledged the sacrifices made by essential workers of color, immigrants, and other marginalized groups, and promised to devote significant resources to safeguard vulnerable workers during the pandemic (Executive Order 13,995, 86 FR 7193 (Jan. 21, 2021); Executive Order 13,999, 86 FR 7211 (Jan. 21, 2021)), there is no indication by Congress (Walsh, 2021) that an equitable and just economic relief policy will materialize. As CRT's interest convergence suggests, the current exclusionary COVID19 economic relief policies deliberately and effectively retain the structural inequities that characterize the modern American state (Limbert \& Bullock, 2005). While the previously discussed local and state-level initiatives highlight a commitment to creative and inclusive policymaking in a time of unprecedented crisis, and offer new avenues through which to meet the needs of undocumented workers, such initiatives are not a panacea for policy shortcomings and injustice perpetuated at the federal level. A comprehensive policy overhaul is needed to address the complex morass of unjust policy related to undocumented workers specifically, and those without status in general.

If the American government continues to discount basic human rights in the policymaking process, the socioeconomic inequalities exacerbated by COVID-19 will continue to have a profound impact for many years on undocumented individuals, many of whom have been without income and are excluded from the social safety net. All workers - including those who are undocumented - should receive core protections and benefits from the society to which they are contributing, as a human right. Policymakers should guarantee that all children and adults in households who file 
taxes with an ITIN should receive the COVID-19 economic stimulus payments and be eligible for expanded child tax credits (Clark et al., 2020; Kerwin \& Warren, 2020). Federal policies should improve immediate access to affordable healthcare by funding low-cost community health clinics, as well as eliminating immigration status requirements for eligibility to access basic social protection programs, such as TANF and SNAP (Clark et al., 2020; Hermansson et al., 2020; Page et al., 2020; Wilson \& Stimpson, 2020). The Biden administration's extension of emergency student financial aid eligibility requirements to include undocumented and DACA students was indicative of positive progress, but more federal level efforts are needed. Lastly, Congress should pass the Biden administration's proposed US Citizenship Act, which aims to provide a pathway to citizenship for millions of undocumented immigrants and would legalize DACA recipients and immigrant farmworkers, therefore opening the door to more opportunities for financial COVID-19 relief support (White House, 2021). Moreover, more than one million people in the USA currently have legal status through the DACA and TPS programs. However, the recent July 2021 federal court rulings on DACA and TPS threaten to take away current legal status, leaving one million people as undocumented and unable to access crucial resources, and in risk of deportation, despite promises from the Biden administration to challenge both rulings (Ramos, 2021). The deportation of one million people, all of whom are working age, would surely devastate the communities (Green, 2019) and industries (Brannon $\&$ McGee, 2019) in which they live and work.

Given that undocumented workers may be fearful of seeking the limited forms of economic support for which they may be eligible due to possible retribution by immigration enforcement authorities, policymakers on the local, state, and federal level should explicitly denounce public charge rhetoric and expunge dehumanizing language from legislation in order to regain the lost trust of the undocumented population (Rafieifar et al., 2021). When local, state, and federal policies and political leaders do engage in unjust, dehumanizing language and storytelling, social workers at the micro, mezzo, and macro levels should engage in critical policy analysis (Romich \& Rodriguez, 2021). Social workers must engage in policy discourse and provide an argument for policies that are affirmative of human rights (Hermansson et al., 2020). At the time of writing this article, there was active discussion in the fields of law (Golden Gate University School of Law, 2021; Lahoud, 2021) and policy (Rojo \& Guzman, 2021; Gomez $\&$ Meraz, 2021) about the injustice of current economic relief policies, but very little in the field of social work (Cross \& Gonzalez Benson, 2021; Rafieifar, 2021). Yet, the field of social work aspires to provide a critical and social justice-minded perspective that considers systems of oppression, power dynamics, and human rights, and this perspective can contribute to interdisciplinary synergy for socially just economic policy development (Romich \& Rodriguez, 2021).

Social work educators can use CRT and LatCrit in their classrooms as frameworks for critiquing social, economic, and health policy. For example, students can identify narratives in policy and social rhetoric of "us" and "them," which are often used to justify exclusionary policies and legislation (Romero, 2008). Students can also use CRT and LatCrit to challenge the dominant Euro- and white-centric narratives (and related policy foci) prevalent in the USA (Trucios-Haynes, 2001). In addition to providing a critical perspective, social workers who work with immigrant and undocumented individuals can serve as a safe bridge to understanding the evolving economic and social policies and the rights and benefits available to individuals based on legal status. Social workers can also advocate for the rights of the undocumented worker through community organizing or by providing community-based opportunities to shape societal discourse about undocumented workers. From the lens of CRT and LatCrit, social workers engaged with communities of color should propose policy solutions that embolden solidarity, rather than competition, among immigrants and citizens of color, both of whom experience discrimination and disadvantage with current economic policies (Romero, 2008).

Social work researchers can collect data about the impacts of exclusionary economic policies to influence policymakers and use their collective voices to demand change. Ultimately, social workers are well-prepared to challenge these particularly insidious instances of systemic injustice and are compelled to do so as per their ethical obligations as defined in the Code of Ethics. As described in the National Association of Social Workers (NASW) Code of Ethics (2021), all social workers are professionally obligated to "promote social justice and social change with and on behalf of clients" and "strive to end discrimination, oppression, poverty, and other forms of social injustice." As theoretical orientations, CRT and LatCrit center the lived experiences of those whose voices are so often silenced and task social work researchers, practitioners, and policymakers with the role to help "raise the volume" of those voices in a way that re-shapes policy to be more equitable and inclusive.

\section{Conclusion}

The COVID-19 pandemic has highlighted the vulnerability of undocumented immigrants at multiple levels in American society and the federal government's consistent failure to enact economic policies that mitigate this 
vulnerability. Following the onset of the COVID-10 pandemic, the undocumented community in the United States was vulnerable to unemployment because of their job sector and COVID-19 contraction if they remained employed. Despite these heightened economic vulnerabilities and more inclusive policy initiatives, undocumented workers were overwhelmingly excluded from enacted federal economic relief policies. CRT is a framework that provides an understanding of the exclusion of undocumented workers within the larger context of economic marginalization and injustice. Current legislation maintains the existing climate of economic inequity. Such policies are anathema to the right to work standards as established in Article 23 of the UDHR, including the right to equal pay, favorable work conditions, and protection against unemployment, as well as the right to an adequate standard of well-being, as protected by UDHR Article 25 (UN, 1948).

The economic ramifications of the global pandemic have been devastating for all, but particularly so for undocumented workers and their families who have been left out of critical assistance. More troublingly, the Congressional Budget Office estimates that labor market conditions will not return to normal before 2024 (Zamarripa \& Roque, 2021). Therefore, effective and immediate economic policies must be enacted to address the growing chasm of inequity in American society as experienced by often-essential undocumented immigrant workers (Svajlenka, 2020). Federal policies must be designed to counter the current injustice of our economic systems and to catalyst social inclusion instead of exclusion (Romich \& Rodriguez, 2021).

\section{References}

American Immigration Council. (2020). The facts about the individual taxpayer identification number. Accessed November 15, 2021. https:// americanimmigrationcouncil.org/research/facts-about-individualtaxpayer-identification-number-itin

Artiga, S., \& Diaz, M. (2019). Health coverage and care of undocumented immigrants. Kaiser Family Foundation. Accessed November 15, 2021. https://kff.org/racial-equity-and-health-policy/issue-brief/ health-coverage-and-care-of-undocumented-immigrants/

Artiga, S., Ndugga, N., \& Pham, O. (2021). Immigrant access to COVID-19 vaccines: Key issues to consider. Kaiser Family Foundation. Accessed November 15, 2021. https://www.kff.org/ racial-equity-and-health-policy/issue-brief/immigrant-access-tocovid-19-vaccines-key-issues-to-consider/

Bernal, D. D. (2002). Critical race theory, Latino critical theory, and critical raced-gendered epistemologies: Recognizing students of color as holders and creators of knowledge. Qualitative inquiry, $8(1), 105-126$.

Bhutta, N., Blair, J., Dettling, L. J., \& Moore, K. B. (2020). COVID19, the CARES Act, and families' financial security. SSRN Electronic Journal, 1-39. https://doi.org/10.2139/ssrn.3631903

Brannon, I., \& McGee, M. K. (2019). Estimating the economic impacts of DACA. SSRN. https://doi.org/10.2139/ssrn.3420511

Bright, C. L. (2020). The two pandemics. Social Work Research, 44(3), 139-142. https://doi.org/10.1093/swr/svaa012
Capps, R., Batalova, J., \& Gelatt, J. (2020a). COVID-19 and unemployment: Assessing the early fallout for immigrants and other U.S.workers. Migration Policy Institute. Accessed November 15, 2021. https://migrationpolicy.org/research/covid-19unemployment-immigrants-other-us-workers

Capps, R., Fix, M., \& Batalova, J. (2020b). Anticipated 'chilling effects' of the public charge rule are real: Census data reflect steep decline inbenefits use by immigrant families. Migration Policy Institute. Accessed November 15, 2021. https://migrationpolicy. org/news/anticipated-chilling-effects-public-charge-rule-are-real

Clark, E., Fredricks, K., Woc-Colburn, L., Bottazzi, M. E., \& Weatherhead, J. (2020). Disproportionate impact of the COVID-19 pandemic on immigrant communities in the United States. PLoS Neglected Tropical Diseases, 14(7), e0008484. https://doi.org/ 10.1371/journal.pntd.0008484

Congressional Research Service. (2021). Temporary protected status and deferred enforced departure. Accessed November 15, 2021. https://sgp.fas.org/crs/homesec/RS20844.pdf

Constance-Huggins, M. (2012). Critical race theory in social work education: A framework for addressing racial disparities. Critical Social Work, 13(2), 1-16.

Cross, F. L., \& Gonzalez Benson, O. (2021). The Coronavirus pandemic and immigrant communities: A crisis that demands more of the social work profession. Affilia, 36(1), 113-119. https:// doi.org/10.1177/0886109920960832

Delgado Bernal, D. (2002). Critical race theory, Latino critical theory, and critical raced-gendered epistemologies: Recognizing students of color as holders and creators of knowledge. Qualitative Inquiry, 8(1), 105-126. https://doi.org/10.1177/107780040200800107

Delgado, R., \& Stefancic, J. (2017). Critical race theory: An introduction (Vol. 20). New York University Press.

Fiscal Policy Institute. (2021). Excluded worker fund will benefit 290,000 undocumented New Yorkers and boost local economies. Accessed November 15, 2021. https://fiscalpolicy.org/ excluded-worker-fund-will-benefit-290000-undocumented-newyorkers-and-boost-local-economies

Flores Morales, J., \& Farago, F. (2021). "Of course we need to help the undocumented immigrants!": Twitter discourse on the (un) deservingness of undocumented immigrants in the United States during the COVID-19 pandemic. Sociological Perspectives. Advance online publication. https://doi.org/10.1177/07311214211005494

Frazee, G. (2018). Four myths about how immigrants affect the U.S. economy. PBS News Hour. Accessed November 15, 2021. https:// pbs.org/newshour/economy/making-sense/4-myths-about-howimmigrants-affect-the-u-s-economy

Frost, A. (2016). Can the government deport immigrants using information it encouraged them to provide. Administrative Law Review Accord, 2(2), 97-110.

Godlee, F. (2020). Racism: The other pandemic. British Medical Journal, 369, Article m2303. https://doi.org/10.1136/bmj.m2303

Golden Gate University School of Law. (2021). COVID-19 and the U.S. federal government vs. undocumented immigrants: How the U.S. excludes undocumented immigrants from financial relief amid a global pandemic. GGU Law Review Blog. 83. Accessed November 15,2021 . https://digitalcommons.law.ggu.edu/ggu_law_ review_blog/83

Goldman, D., Smith, J., \& Sood, N. (2005). Legal status and health insurance among immigrants. Health Affairs, 24(6), 1640-1653.

Gomez, J. C., \& Meraz, V. (2021). Immigrant families during the pandemic: On the frontlines but left behind. The Center for Law and Social Policy. Accessed November 15, 2021. https://clasp.org/ publications/report/brief/immigrant-families-pandemic-frontlines

Gould, E., Perez, D., \& Wilson, V. (2020). Latinx workers - particularly women - face devastating job losses in the COVID-19 recession. Economic Policy Institute. Accessed November 15, 2021. https://epi.org/publication/latinx-workers-covid/ 
Green, J. (2019). Under the cloud of deportation threat: Testimonios reveal impact on mixed-status families. Hispanic Journal of Behavioral Sciences, 41(2), 127-144.

Hartlep, N. D. (2009). Critical race theory: An examination of its past, present, and future implications. ERIC. Accessed November 15, 2021. https://eric.ed.gov/fulltext/ED506735.pdf

Hermansson, L., Lundberg, A., Gruber, S., Jolly, A., Lind, J., Righard, E., \& Scott, H. (2020). Firewalls: A necessary tool to enable social rights for undocumented migrants in social work. International Social Work. Advance Online publication. https://doi.org/10. $1177 / 0020872820924454$

Joint Economic Committee. (2020). Immigrants, the economy, and the COVID-19 outbreak. U.S. Congress. https://www.jec.senate. gov/public/_cache/files/9e9c9042-6ff9-4f6c-8d65-fbe2625d21 43/immigrants-the-economy-and-the-covid19-outbreak-final1.pdf

Kerwin, D., \& Warren, R. (2020). US Foreign-born workers in the global pandemic: Essential and marginalized. Journal on Migration and Human Security, 8(3), 282-300. https://doi.org/10.1177/ 2331502420952752

Lahoud, R. G. (2021). Three stimulus packages, and undocumented immigrants still struggle without aid. The National Law Review. Accessed November 15, 2021. https://natlawreview.com/ article/three-stimulus-packages-and-undocumented-immigrantsstill-struggle-without-aid

Limbert, W., \& Bullock, H. (2005). 'Playing the fool': US welfare policy from a critical race perspective. Feminism \& Psychology, $15,253-274$.

Lipman, F. J. (2006). The taxation of undocumented immigrants: Separate, unequal, and without representation. Harvard Latino Law Review, 9, 1-58.

Luyten, J., \& Beutels, P. (2016). The social value of vaccination programs: Beyond cost-effectiveness. Health Affairs, 35(2), 212-218.

Maldonado, A. S. (2021). The risk of being essential: A quantitative study on essential workers of color during the Covid-19 pandemic [Unpublished doctoral dissertation]. California State University, Fresno.

Mayor's Office, City of New York. (2020). Mayor de Blasio announces New York City COVID-19 immigrant emergency relief program with open society foundations. Accessed November 15, 2021. https://www1.nyc.gov/office-of-the-mayor/news/262-20/ mayor-de-blasio-new-york-city-covid-19-immigrant-emergencyrelief-program-open

Migration Policy Institute. (2018). Profile of the unauthorized population: United States. https://migrationpolicy.org/data/ unauthorized-immigrant-population/state/US

National Association of Social Workers. (2021). NASW Code of Ethics. https://www.socialworkers.org/About/Ethics/Code-of-Ethics/Code-of-

National Immigration Law Center. (2012). Facts about the individual taxpayer identification number (ITIN). Accessed November 15, 2021. https://www.nilc.org/wp-content/uploads/2015/12/ITINfacts-2012-09.pdf

National Immigration Law Center. (2020a). Shared crisis, shared solutions: State and local advocacy for an immigrant-inclusive response to the COVID-19 crisis. Accessed November 15, 2021. https://www.nilc.org/resources-covid19-crisis-andconsequences/covid-19-shared-crisis-shared-solutions/

National Immigration Law Center. (2020b). Understanding the impact of key provisions of COVID-19 relief bills on immigrant communities. Accessed November 15, 2021. https://www.nilc.org/issues/ economic-support/impact-of-covid19-relief-bills-on-immigrantcommunities

National Migration Forum. (2018). Fact sheet: Immigrants and public benefits. Accessed November 15, 2021. https://immigratio nforum.org/article/fact-sheet-immigrants-and-public-benefits
Page, K. R., Venkataramani, M., Beyrer, C., \& Polk, S. (2020). Undocumented US immigrants and Covid-19. New England Journal of Medicine, 382(21), e62. https://doi.org/10.1056/NEJMp2005953

Passel, J., \& Cohn, D. (2018). Unauthorized immigrant workforce is smaller, but with more women. Pew Research Institute. Accessed November 15, 2021. https://pewresearch.org/hispanic/2018/11/27/u-s-unauthorizedimmigrant-total-dips-to-lowest-level-in-a-decade/

Pérez Huber, L. (2010). Using Latina/o critical race theory (LatCrit) and racist nativism to explore intersectionality in the educational experiences of undocumented Chicana college students. Journal of Educational Foundations, 24(1-2), 77-96.

Rafieifar, M., Naseh, M., Potocky, M., Zajicek-Farber, M. L., Kim, W., Padilla, B., Ortiz, R. M., \& Lopez, J. A. (2021). Impacts of COVID-19 on refugees and immigrants in the United States: A call for action. International Social Work, 64(5), 771-776. https:// doi.org/10.1177/00208728211017964

Ramos, D. (2021). Immigrants under TPS and DACA are entering a crucial phase in confronting the future of immigration policy. USC Annenberg Media. Accessed November 15, 2021. https:// www.uscannenbergmedia.com/2021/08/11/immigrants-under-tpsand-daca-are-entering-a-crucial-phase-in-confronting-the-futureof-immigration-policy/

Reed, H. (2018). Forced migration and undocumented migration and development. CUNY Institute for Demographic Research. Accessed November 15, 2021. https://un.org/en/development/desa/population/ events/pdf/expert/28/EGM_Holly_Reed.pdf

Rojo, J., \& Guzman, C. E. V. (2021). Strengthening all communities for a brighter future. New Mexico Voices for Children. Accessed November 15, 2021. https://www.nmvoices.org/wp-content/uploads/2021/ 02/ImmigrationReport-web.pdf

Romero, M. (2008). Crossing the immigration and race border: A critical race theory approach to immigration studies. Contemporary Justice Review, 11(1).

Romich, J., \& Rodriguez, M. Y. (2021). There and back again: A commentary on social welfare policy in the wake of 2020. Journal of the Society for Social Work and Research, 12(1), 1-10. https:// doi.org/10.1086/713020

Singer, A., \& Svajlenka, N. (2013). Immigration facts: Deferred action for childhood arrivals (DACA). Metropolitan Policy Program at Brookings. Accessed November 15, 2021. https://brookings.edu/ wp-content/uploads/2016/06/DACA_singer_svajlenka_FINAL. pdf

Solomon, D., Maxwell, C., \& Castro, A. (2019). Systematic inequality and economic opportunity. Center for American Progress. Accessed November 15, 2021. https://www.americanprogress.org/issues/ race/reports/2019/08/07/472910/systematic-inequality-economicopportunity/

Suro, R., \& Findling, H. (2020). State and local aid for immigrants during the COVID-19 pandemic: Innovating inclusion. The Center for Migration Studies. Accessed November 15, 2021. https://cmsny. org/publications/state-local-aid-immigrants-covid-19-pandemicinnovating-inclusion/

Svajlenka, N. (2020). Protecting undocumented workers on the pandemic's front lines: Immigrants are essential to America's recovery. Center for American Progress. Accessed November 15, 2021. https://americanprogress.org/issues/immigration/ reports/2020/12/02/493307/protecting-undocumentedworkers-pandemics-front-lines/

Svajlenka, N., \& Wolgin, P. (2020). What we know about the demographic and economic impacts of DACA recipients: Spring 2020 Edition. Center for American Progress. Retrieved November 15, 2021, from https://americanprogress.org/issues/immigration/news/ 2020/04/06/482676/know-demographic-economic-impacts-dacarecipients-spring-2020-edition/ 
Trucios-Haynes, E. (2001). Why "race matters:” Latcrit Theory and Latina/o Racial Identity. La Raza Law Journal, 12(1), 1-42.

United Nations. (1948). Universal Declaration of Human Rights.

United Nations. (1990). International Convention on the Protection of the Rights of All Migrant Workers and Members of their Families.

Walsh, D. (2021). Here are 5 hurdles that democrats face now for their $\$ 3.5$ trillion budget. National Public Radio. https://npr.org/2021/ 08/12/1026184120/here-are-5-hurdles-that-democrats-face-nowfor-their-3-5-trillion-budget

Werner, E. (2020). House Democrats pass $\$ 3$ trillion coronavirus relief bill despite Trump's veto threat. Washington Post. https://www. washingtonpost.com/us-policy/2020/05/15/democrats-pelosicongress-coronavirus-3-trillion-trump/

The White House. (2021). Fact sheet: President Biden sends immigration bill to Congress as part of his commitment to modernize our immigration system. Accessed November 15, 2021. https://www. whitehouse.gov/briefing-room/statements-releases/2021/01/20/factsheet-president-biden-sends-immigration-bill-to-congress-as-partof-his-commitment-to-modernize-our-immigration-system/
Wilson, F. A., \& Stimpson, J. P. (2020). US policies increase vulnerability of immigrant communities to the COVID-19 pandemic. Annals of Global Health, 86(1), 57. https://doi.org/10.5334/aogh.2897

Wood, L. C. (2018). Impact of punitive immigration policies, parentchild separation and child detention on the mental health and development of children. BMJ Paediatrics Open, 2(1), e000338. https://doi.org/10.1136/bmjpo-2018-000338

Zamarripa, R., \& Roque, L. (2021). Latinos face disproportionate health and economic impacts from COVID-19. Center for American Progress. Accessed November 15, 2021. https:// americanprogress.org/issues/economy/reports/2021/03/05/ 496733/latinos-face-disproportionate-health-economicimpacts-covid-19/

Publisher's Note Springer Nature remains neutral with regard to jurisdictional claims in published maps and institutional affiliations. 